\title{
Effects of dominance status on defensive burying in male mice
}

\author{
LESLIE R. MEEK, TERESA M. DALAGER, and ERNEST D. KEMBLE \\ University of Minnesota, Morris, Minnesota
}

\begin{abstract}
Two experiments with male mice explored the effects of intermale dominance status on defensive burying. In the first experiment, there was no relationship between readiness to enter a novel open field and conditioned defensive burying, but males showing extensive scarring near the base of the tail, associated with lower dominance status, defensively buried less than did their unscarred, and presumably more dominant, counterparts. In the second experiment, mice that were dominant in a food competition test showed significantly more unconditioned, but not conditioned, burying than did those that were subordinate. The results of these experiments suggest that prior intermale dominance interactions contribute to an animal's propensity to defensively bury.
\end{abstract}

A number of studies clearly indicate that the incidence of defensive burying in rodents is importantly determined by experimental manipulations that alter levels of fearfulness. Treatment with anxiolytic drugs produces a decrease in defensive burying (Treit, 1987; Treit, Pinel, \& Fibiger, 1981; Tsuda, Ida, \& Tanaka, 1988b). This effect is also antagonized by several putative anxiogenic compounds (Treit, 1987). Increasing levels of electric shock (Treit, Pinel, \& Terlecki, 1980) or treatment with the anxiogenic drug yohimbine (Tsuda et al., 1988b) also enhances the response. Taken together, these data suggest a positive relationship between increasing levels of fear and defensive burying. The evidence on this point is not entirely consistent, however. Conspecific stress odors or inescapable pretest shock administration (Williams, 1987a, 1987b), septal-area lesions (Gray, Terlecki, Treit, \& Pinel, 1981), or treatment with fluprazine hydrochloride (Meek, Gibson, \& Kemble, 1989) all seem to increase fearfulness but to inhibit defensive burying. Thus, at some levels and/or under some testing conditions, increased fear may suppress, rather than increase, defensive burying. The present experiments were undertaken to explore further the relationship between fearfulness and defensive burying.

\section{EXPERIMENT 1}

Exploration of novel environments is differentially altered by a number of pharmacological treatments. Anxiolytic drugs increase (e.g., see Chopin, Pillow, \& File, 1986; Yamamoto \& Ueki, 1987), whereas putative anxiogenic agents suppress, exploration (e.g., see Chopin et al., 1986; Kemble, Thornton, \& Schultz, 1987). To the extent that this behavioral measure reflects fearfulness, then, some relationship between an animal's readiness to ex-

Please address reprint requests to Ernest Kemble, Division of Social Sciences, University of Minnesota-Morris, Morris, MN 56267. plore novel environments and its propensity to defensively bury might be expected. Experiment 1 was designed to explore this relationship.

\section{Method}

Subjects. Thirty experimentally naive male CD-1 mice, weighing 31.5-39.0 g, served as subjects. These animals were housed in all-male groups of 8-12 for 40-50 days prior to the beginning of the experiment. Five days before testing, the mice were individually housed in $20.0 \times$ $26.5 \times 41.0 \mathrm{~cm}$ glass aquariums with $5.0-\mathrm{cm}$ wood-shavings substrates. Food and water were available ad lib.

Apparatus. Exploration was tested in a $60.0 \times 40.0 \times 40.5 \mathrm{~cm}$ open field. Three walls were constructed of white Plexiglas, one wall and the ceiling of clear Plexiglas, and the floor of flat gray plywood. Illumination was provided by nine $7-\mathrm{W}$ incandescent bulbs suspended $6.0 \mathrm{~cm}$ above the apparatus ceiling, and extraneous sound was masked by a small ventilation fan. The subjects were confined in a $16.5 \times 10.0 \times 9.0 \mathrm{~cm}$ black Plexiglas startbox with a sliding guillotine door at one end. Latencies to enter and time spent in the open field were measured by stopwatch. Conditioned defensive burying was examined in the home aquarium and was elicited by a white plastic vial, $2.5 \mathrm{~cm}$ in diameter and $6.0 \mathrm{~cm}$ long, that contained a Sylvania Blue Dot flashbulb connected to a hand-held battery and switch by thin insulated wires.

Procedure. The mice were placed in the black startbox, which, in turn, was placed in the center of the open field. Thirty minutes later, the startbox door was opened, and latency to enter the open field, time spent in the open field, and number of entrances were recorded for $10 \mathrm{~min}$. Two days later, food and water were removed from the aquarium, the wood-shavings substrate was leveled, and the flashbulb apparatus was placed on the floor of the aquarium opposite the mouse. When the mouse approached within $2.0 \mathrm{~cm}$ of the flashbulb apparatus, the experimenter depressed the hand-held switch, causing the bulb to flash. Latency to initiate defensive burying and its duration were recorded by stopwatch for $10 \mathrm{~min}$. Height of bedding around the flashbulb apparatus was recorded at the end of the trial.

\section{Results}

Latencies to enter the open field varied widely across mice, ranging from 2.44 to $600.00 \mathrm{sec}(M=113.10 \mathrm{sec}$, $S D=56.20 \mathrm{sec})$. The defensive burying of the 8 mice exhibiting the shortest entrance latencies $(M=14.24 \mathrm{sec}$, range $=2.44-25.28 \mathrm{sec}$ ) was compared with that of the 8 mice exhibiting the longest latencies $(M=505.73 \mathrm{sec}$, range $=175.54-600.00 \mathrm{sec})$. There were no suggestions 
of group differences in latency to initiate defensive burying (short-latency group, $M=190.61 \mathrm{sec}$; long-latency group, $M=223.83 \mathrm{sec}$ ), duration of defensive burying (short, $M=41.70 \mathrm{sec}$; long, $M=79.22 \mathrm{sec}$ ), or height of bedding piles (short, $M=8.1 \mathrm{~mm}$; long, $M=9.0 \mathrm{~mm}$, all $p \mathrm{~s}>.10)$. Correlational analysis also revealed only a weak relationship between latency to enter the open field and duration of defensive burying $(r=+0.27)$.

In the course of testing, it was noted that some mice showed extensive scarring on the back near the base of the tail. Since this is the favored attack site by offensive males (Blanchard, O'Donnell, \& Blanchard, 1979), it seemed reasonable to assume that dominance status during earlier group housing could be inferred by degree of scarring in this region. We were able to identify 9 mice with extensive posterior-dorsal scarring (thus suggesting submissive social status) and 12 , presumably dominant, mice with no visible scars. Dominant mice $(M=68.11 \mathrm{sec})$ engaged in defensive burying for longer durations than did their submissive counterparts $[M=22.00 \mathrm{sec}, t(19)=2.52, p<.05]$. The height of bedding piles was marginally greater among dominant mice [dominant, $M=9.5 \mathrm{~mm}$; submissive, $M=6.8 \mathrm{~mm}, t(19)=2.03, .10>p>.05]$. Although the dominant mice tended to initiate defensive burying $(M=121.04 \mathrm{sec})$ more quickly than did the submissive mice $(M=291.37 \mathrm{sec})$, these differences were not statistically significant $(t<1.0)$. Latencies to enter the open field were quite similar among dominant $(M=153.27 \mathrm{sec})$ and submissive $(M=134.81 \mathrm{sec})$ mice, with no suggestion of group differences $(t<1.0)$.

\section{EXPERIMENT 2}

Experiment 1 suggests that prior intermale agonistic interactions, and the resulting dominance relationships, contribute to an animal's readiness to defensively bury. It further suggests that dominance, rather than submission, increases the incidence of the response. Because no direct measures of dominance were available in Experiment 1, however, an obvious shortcoming of this experiment was the use of scarring to infer past social status. Although this measure seems to be a reasonably sensitive measure of dominance, it is also possible that a host of other variables might have contributed to the group differences. In Experiment 2, therefore, a number of experimental manipulations were utilized to promote intermale agonistic interactions, and the defensive burying of empirically defined dominant and submissive animals was compared. In addition, both conditioned and unconditioned defensive burying were examined in this study.

\section{Method}

Subjects. Thirty-six experimentally naive male CD-1 mice, weighing 26.0-32.0 $\mathrm{g}$ at the beginning of testing, served as subjects. Six groups of 6 mice were formed by pairing 3 male littermates from one litter with 3 from another. All mice within the groups were similar in body weight $( \pm 2.0 \mathrm{~g})$, and each mouse was tail marked to permit individual identification. Each group was housed for 24 days in a $51.0 \times 25.5$ $\times 32.0 \mathrm{~cm}$ glass aquarium containing food, water, and a wood-shavings substrate. The mice were then individually housed in $35.5 \times 25.5 \times$ $32.0 \mathrm{~cm}$ glass aquariums (furnished as described above) for habituation and behavioral testing.

Apparatus and Procedures. Beginning $24 \mathrm{~h}$ after group formation, the aggressive behavior of each mouse was observed for $10 \mathrm{~min} / \mathrm{day}$ for 7 consecutive days (order of observations was counterbalanced within groups). Number of offensive (lateral attack, chase, bite) and defensive (defensive upright, flee) behaviors were tallied during each observation period. On the 12 th day, a single adult female mouse was introduced into the aquarium for 5 days; number of mounts and intromissions were tallied for 5 days, as described above. On Days 20-24, a single piece of chocolate candy (M\&Ms) was placed in the aquarium, and the duration of candy possession was recorded for each mouse. This procedure was continued until five chocolates were consumed each day. The mice were then individually housed for 4 days of habituation. On the 5th and 6th days, conditioned and unconditioned burying behavior were recorded. Each animal was tested for both conditioned and unconditioned burying, with the order of testing counterbalanced within groups. Conditioned burying was measured as described in Experiment 1. We assessed unconditioned burying by placing a $15-\mathrm{cm}$-long tiger salamander (Ambystoma tigrinum) in the aquarium opposite the mouse and recording the latency to initiate defensive burying and its duration, for $10 \mathrm{~min}$.

\section{Results}

It was not possible to utilize the frequency of intermale attack or copulatory behavior to unambiguously identify dominant and submissive mice. During 7 days of observations, only 5 mice were observed to offensively attack, and only 9 mice were observed to copulate. Moreover, in some groups, patterns of intermale attack shifted markedly over time, particularly after the introduction of the female. It should be noted, however, that some bite wounds near the base of the tail were evident in most groups at the beginning of observation periods, indicating reasonable, although unfortunately unobserved, levels of intermale agonistic behavior. Total duration of candy possession for the 5 days of testing was, therefore, used to assess dominance status. Within each group of 6 mice, the 2 mice that exhibited the greatest total possession time were designated as dominant, while the 2 mice exhibiting shortest possession times were designated submissive. Of the 12 mice designated as dominant, 5 maintained possession for more than $600 \mathrm{sec}(M=458.5 \mathrm{sec}$, range = $195-1,241 \mathrm{sec}$ ), while 5 of 12 submissive mice never had possession of the candy $[M=54.3 \mathrm{sec}$, range = $0-311 \mathrm{sec}, U(12,12)=4, p<.002]$. The dominant mice also engaged in significantly more unconditioned defensive burying $(M=13.6 \mathrm{sec}$, range $=0-52 \mathrm{sec})$ than did the submissive mice $[M=1.7 \mathrm{sec}$, range $=0-10 \mathrm{sec}$, $U(12,12)=35, p<.05]$. Although the dominant mice also exhibited slightly more conditioned defensive burying $(M=5.1 \mathrm{sec}$, range $=0-50 \mathrm{sec})$ than did the submissive mice $(M=0.4 \mathrm{sec}$, range $=0-3 \mathrm{sec})$, the data of the two groups overlapped extensively with no statistically significant differences $(p s>.10)$. There were no reliable differences in latency to initiate defensive burying on either measure $(p s>.10)$.

\section{DISCUSSION}

These experiments indicate that intermale dominance experience significantly alters an animal's tendency to defensively bury. Interestingly, 
however, the data suggest that dominance, rather than submissiveness, increases the vigor of the response. If submissive animals are presumed to exhibit higher levels of generalized fearfulness than do their dominant counterparts, then, as our results also suggest, some levels of fear inhibit the response. The effectiveness of inescapable shock (Williams, 1987a, 1987b), conspecific stress odors (Williams, 1987b), or septal lesions (Gray et al., 1981) in suppressing defensive burying also suggests a similar conclusion. Furthermore, Wistar albino rats have been shown to freeze more (implying higher fear levels) and to defensively bury less than do hooded rats (Tsuda, Ida, \& Tanaka, 1988a). These data are consistent in suggesting that fear may effectively inhibit defensive burying. Since other fear-inducing manipulations do increase the incidence of defensive burying (e.g., see Treit et al., 1980), however, it seems clear that fear and defensive burying are not monotonically related. In this connection, Moser and Tait (1983) found that rats engaged in defensive burying only after they froze and/or escaped from an aversive stimulus. We, too, have noted that defensive burying occurs most often after a delay of several minutes. This delayed emergence of the response may result from a gradual decrease in initially high, and suppressive, levels of fear. Taken together, the above data are congruent in suggesting that defensive burying is facilitated by moderate fear but suppressed at higher levels. If this interpretation is correct, then defensive burying may not be best characterized as defensive in nature. Further studies of the relationship between fear and defensive burying are needed to clarify this issue, however.

The present studies also make it clear that the social experiences of animals used in studies of defensive burying require careful attention. Group housing and habituation to the experimental apparatus are commonly employed in this research (e.g., Pinel, Hoyer, \& Terlecki, 1980; Treit et al., 1981; Tsuda et al., 1988a) and increase the probability of agonistic encounters among experimental animals. Such procedures may well influence experimental outcomes. Furthermore, the fact that the mice in Experiment 1 showed substantially higher levels of defensive burying than did those in Experiment 2 (which were group housed for a shorter time) suggests that duration and/or intensity of prior social interactions may be an important determinant of suppressive or potentiating effects, and that it may have longer term effects on the phenomenon as well. This possibility would seem to merit careful consideration.

\section{REFERENCES}

Blanchard, R. J., O'Donnell, V., \& Blanchard, D. C. (1979). Attack and defensive behaviors in the albino mouse. Aggressive Behavior, 5, 341-352.

Chopin, P., Pillow, S., \& File, S. E. (1986). The effects of yohim- bine on exploratory and locomotor behavior are attributable to its effects at noradrenaline and not benzodiazepine receptors. Neuropharmacology, 25, 53-57.

Gray, D. S., Terlecki, L. J., Treit, D., \& Pinel, J. P. J. (1981). Effect of septal lesions on conditioned defensive burying. Physiology \& Behavior, 27, 1051-1056.

Kemble, E. D., Thornton, A. E., \& Schulz, L. A. (1987). Some fear-potentiating effects of fluprazine hydrochloride in mice. Aggressive Behavior, 13, 269-280.

MeeK, L. R., Gibson, B. M., \& Kemble, E. D. (1989). Effects of fluprazine hydrochloride on reactivity to a non-conspecific intruder. Psychological Record, 39, 203-210.

Moser, C. G., \& TAIT, R. W. (1983). Environmental control of multiple defensive responses in a conditioned burying paradigm. Journal of Comparative Psychology, 97, 338-352.

Pinel, J. P. J., Hoyer, E., \& Terlecki, L. J. (1980). Defensive burying and approach-avoidance behavior in the rat. Bulletin of the Psychonomic Society, 16, 349-352.

Treit, D. (1987). Ro 15-1788, CGS 8216, picrotoxin, and pentylenetetrazol: Do they antagonize anxiolytic drug effects through an anxiogenic action? Brain Research Bulletin, 19, 401-405.

Treit, D., Pinel, J. P. J., \& Fibiger, H. C. (1981). Conditioned defensive burying: A new paradigm for the study of anxiolytic agents. Pharmacology, Biochemistry \& Behavior, 15, 619-626.

Treit, D., Pinel, J. P. J., \& Terlecki, L. J. (1980). Shock intensity and conditioned defensive burying in rats. Bulletin of the Psychonomic Society, 16, 5-7.

TsudA, A., IDA, Y., \& TANAKA, M. (1988a). Behavioral field analysis in two strains of rats in a conditioned defensive burying paradigm. Animal Learning \& Behavior, 16, 354-358.

Tsuda, A., IdA, Y., \& TANAKA, M. (1988b). The contrasting effects of diazepam and yohimbine on conditioned defensive burying in rats. Psychobiology, 16, 213-217.

Williams, J. L. (1987a). Effects of shock controllability on alpha male aggression and defense, defeat of intruders, and defensive burying. Psychological Record, 37, 369-380.

WiLLIAMS, J. L. (1987b). Influence of conspecific stress odors and shock controllability on conditioned defensive burying. Animal Learning \& Behavior, 15, 333-341.

Yамамото, T., \& UeKI, S. (1987). A new method for screening anxiolytic drugs in rats. Pharmacology, Biochemistry \& Behavior, 26, 111-117.

(Manuscript received January 25, 1989.) 